\title{
Early Exposure to Service- Learning and College Success Beyond the Freshman Year
}

Wei Song

University of Minnesota

Andrew Furco

University of Minnesota

Geoffrey Maruyama

University of Minnesota

Isabel Lopez

University of Minnesota

\section{Recommended Citation:}




\title{
Early Exposure to Service-Learning and College Success Beyond the Freshman Year
}

\author{
Wei Song, Andrew Furco, Geoffrey Maruyama, and Isabel Lopez \\ University of Minnesota
}

\begin{abstract}
Postsecondary institutions continue to search for effective approaches that enhance the educational success of their students, especially underrepresented students. For the longitudinal archival study discussed in this article, the authors investigated the role that students' participation in service-learning during their first year of college played in their educational success. Two cohorts of undergraduate students who entered a large public research university in fall 2011 and fall 2012 were analyzed. By following the two cohorts for five or six years (up to fall 2017), the authors examined the differences in various educational outcomes between students who participated in a service-learning course during their first year and those who did not take service-learning courses throughout their college years. To account for students' pre-college academic performance and personal characteristics, the authors used propensity score matching (PSM) to form comparison groups for each of the two treatment cohorts, and they performed parallel analyses for both the full sample and a sub-sample that included only underrepresented students. Analyses of the full sample revealed that for both the 2011 and 2012 cohorts, students who took a service-learning course in the first year achieved higher year-to-year cumulative GPAs and had significantly higher four-year graduation rates than did students who did not participate in service-learning during their college years. The findings for the underrepresented student subsample were similar but less consistent. Among explanations for the difference is less power given the smaller sample. However, more data are yet needed to understand better the relation of first-year service-learning participation among underrepresented students with educational success compared to students from the overall student population. Implications for future research are discussed.
\end{abstract}

Keywords: service-learning, first-year, college success, underrepresented students

Increasingly, as global society moves deeper into an information age in which knowledge production and use are essential for preparing young people for success, universities face two critical institutional pressures. The first pressure centers on the need to increase enrollment numbers to meet the workforce demands of an expanding and quickly evolving 21 ${ }^{\text {st }}$-century global economy (Bauer-Wolf, 2017; Haskins, Holzer, \& Lerman, 2009). The second focuses on improving retention and completion rates (Hughes, 2012), especially among the growing population of students from marginalized and underrepresented populations, such as first-generation college attendees, students from low-income backgrounds, and students of color. At present, the overall retention and completion rates for all college students are far below what is desirable. In the United States, only $39 \%$ of full-time undergraduate students who enrolled as freshmen at a four-year, degree-granting institution in fall 2007 graduated within four years; the five- and six-year graduation rates are equally unimpressive, with only $55 \%$ of students graduating within five years, and $59 \%$ graduating within six years (Kena et al., 2015). Moreover, with the exception of Asian American students, the graduation rates for students from historically underserved population are even lower (Duncheon \& Tierney, 2014). For example, in 2014, only $36.2 \%$ of African-American, $41.9 \%$ of Native Hawaiian or Other Pacific Islander, and $49.4 \%$ of Hispanic students graduated after six years; for Asian American students, the six-year graduation rate was $69.4 \%$ (Ginder, Kelley- Reid, \& Mann, 2015). With a larger percentage of students from historically underrepresented groups entering college each year, higher education institutions need to find ways to ensure greater student retention and degree completion if the United States is to remain competitive in the future global economy.

Recent studies reveal that students who leave college are most likely to do so during or by the end of their first year. Among students who entered college two year colleges in fall 2015, only 58\% were still 
enrolled after the first year (i.e., enrolled in fall 2016) (ACT, 2017). This means that almost half of all students who begin two-year colleges do not persist after the first year. Kelly (2014) suggests that this high stop-out rate may be due to the increasing number of students, especially students from underrepresented backgrounds, who enter college underprepared for college-level work. This lack of adequate preparation for college is associated with both higher levels of college disaffection and lower levels of student reenrollment beyond the first year of college (Barbatis, 2010).

Research on college students' educational success also indicates that the freshman year is an especially critical adjustment period for students. For all students, the first year of college is a time of transition during which students must learn to successfully navigate the academic and social demands of college. This period of adjustment can be especially challenging for students from historically underrepresented backgrounds given that, when compared to other student groups, they face greater hurdles in making the adjustments and are likely to be less prepared to adjust to college successfully (Hurtado, Han, Sáenz, Espinosa, Cabrera, \& Cerna, 2007). As Stavrianopoulos (2008) asserts, the less prepared students are to make these adjustments, and the more adjustments they have to make, the higher the likelihood that they stop-out of college.

To address these conditions, institutions of higher education are in search of effective strategies that can promote students' success during the freshman year and beyond. Over the last several years, there has been an increase in the implementation of interventions designed to bolster students' institutional and academic engagement. Higher levels of student engagement are associated with higher levels of college student retention and graduation (Bringle, Hatcher, \& Muthiah, 2010; Pascarella \& Terenzini, 2016; Tinto, 2003). Findings from studies of college students' institutional engagement have found that such engagement is lowest for students from underrepresented populations. Hurtado (2007) suggests that this is likely because underrepresented students are most likely of all student groups to experience difficulty in finding connections to peers and the campus. A lack of connection to the institution, especially during students' first year of college, is related to higher levels of academic disengagement and lack of persistence (Hurtado, 2007; Próspero \& Vohra-Gupta, 2007).

One of the interventions that higher education institutions are adopting to increase students' institutional and academic engagement is service-learning. Service-learning is a participation-intensive and reflection-intensive curricular intervention that includes constructivist learning activities, cooperative learning, active reflection, critical thinking, curricular alignment to students' interests, and authentic learning activities, all of which have been found to facilitate college student engagement (Kuh, Kinzie, Buckley, Bridges, \& Hayek, 2011). Studies of service-learning reveal that by deepening student engagement, service-learning participation can lead to enhanced academic achievement and educational success (Celio, Durlak, \& Dymnicki, 2011). These studies have found service-learning participation is associated with higher levels of students' intention to continue study (Gallini \& Moely, 2003; Keup, 2005), second-year enrollment (Bringle et al., 2010), and graduation (Lockeman \& Pelco, 2013).

Given that students who stop-out of college are most likely to do so after their first year, it would seem that engaging students in service-learning during the early years of their college experience would enhance the likelihood of their institutional engagement, and ultimately their persistence and graduation. However, the research on service-learning has revealed little regarding when, during the college years, it is most advantageous for students to engage in service-learning. Within the literature on service-learning best practices, there is the suggestion that students are more likely to benefit from service-learning if they are well-prepared for their service activities and have the requisite skills to take on the community-based tasks (Eyler, 2000). As Eyler (2000) suggests, because first-year students may be less prepared to perform highquality service-learning activities, they might not realize the purported educational benefits of servicelearning. Therefore, one might conclude that service-learning is perhaps most beneficial for students if they participate in their later years in college, when students are more likely to possess the necessary skills and knowledge to have a high quality service-learning experience.

Given the particular adjustments and challenges that freshmen face, we sought to explore whether providing first-year students with an authentic, active-learning educational practice through servicelearning might in fact provide them with positive benefits. We hypothesized that by having the potential to bolster underrepresented students' institutional and academic engagement, service-learning participation in 
the early years can lead to greater student persistence and retention. Imbedded in this hypothesis is an assumption that for underrepresented students in particular, off-campus experiences provide opportunities for students to connect back with their communities and to connect their coursework to the societal issues that concern them (Hurtado, 2007). Based on this hypothesis and assumption, we conducted a study at a large research university in the midwestern United States in which we investigated the association between service-learning participation in the first year of college and students' academic outcomes and educational success.

For the study, we identified two cohorts of entering freshmen - students who first enrolled in the university in 2011 and students who first enrolled in 2012 - and followed their educational advancement over six and five years, respectively (through 2017). We first assessed whether or not students participated in service-learning during their first year at the university; if they did, we defined them as our treatment group. From within this group, we then established a second group composed solely of underrepresented students based on underrepresented student categories defined by the U.S. Department of Education: firstgeneration college attendees; students from low socioeconomic backgrounds; and students of color. We then compared the educational outcomes of the overall sample of students who participated in servicelearning during their first year with the educational outcomes of comparable students at the university who did not have a service-learning experience in their first year or at any other point during their college years. We then conducted the same comparison with only underrepresented students in the treatment and comparison groups.

\section{Does When Students Participate in Service-Learning Matter?}

Regardless of when students participate in service-learning, recent study findings have confirmed previous research regarding the various positive effects of service-learning participation on students' academic success in college, including higher final grade point averages (GPAs) and higher graduation rates (Mungo, 2017; Song, Furco, Lopez, \& Maruyama, 2017); these findings apply to students from represented and historically underrepresented groups (Lockeman \& Pelco, 2013). Fewer studies have assessed the benefits of service-learning based on the point in time during college that students participate in service-learning. Yue and Hart (2017) applied an event history analysis to account for time effect (i.e., when students participate in the treatment). Consistent with other research, their results found that enrollment in at least one service-learning course increased students' likelihood of graduation by $25.4 \%$ within six years. However, their investigation revealed that the term in which students' enrolled in service-learning courses was not significantly related to graduation.

Several studies have focused on the impact of early service-learning participation on students' retention from the first to second year. For instance, Keup (2005) found that participation in service-learning during the first year produced a marginally significant odds ratio, indicating a $14 \%$ increase in participating students' intent to re-enroll in the second year. Another study of college freshmen from 11 universities in the state of Indiana revealed a positive correlation between taking a service-learning course in the first year and students' second-year retention (Bringle et al., 2010). Yet, these studies did not fully examine the longer term retention outcomes.

As was mentioned previously, college attrition is most likely to occur during or immediately after the first year (Tinto, 2003). Students' overall adjustment during their first college year is a key to ensuring reenrollment at the institution (Engle, 2007). To help students make successful transitions to college, many programs and course-based strategies, including service-learning, have been developed specifically to strengthen the first-year experience (Barefoot, 2007; DeAngelo, 2014; Zlotkowski, 2002).

In our study, we hypothesized that a positive association between first-year service-learning participation and students' academic outcomes manifests because, in service-learning, students are typically urged to interact with others (peers, faculty, community partners) to complete tasks (Celio et al., 2011). In their study of the effects of service-learning on student retention, Bringle, Hatcher, and Muthiah (2010) found that students reported better peer interaction, faculty interaction, and personal relevance in servicelearning courses than in other courses. In addition, the types of academic exchanges that service-learning 
4 | International Journal of Research on Service-Learning and Community Engagement

encourages (i.e., discussing course content with other students outside of class, studying with other students, interacting with faculty out of class, having intellectual discussions with students from other races and/or ethnicities) are positively associated with first-year students' intention to return to the institution for a second year (DeAngelo, 2014). The enhanced academic and social integration that service-learning fosters might explain service-learning's potential to have a positive influence on first-year students' ability to adjust to college and their overall institutional and academic engagement.

\section{Underrepresented Students in College}

Students from historically underrepresented backgrounds are more likely to withdraw from college and have lower levels of educational achievement than students who are White, have higher socioeconomic statuses (SES), and have college-educated parents (Engle \& Tinto, 2008; Pascarella \& Terenzini, 2016). Underrepresented students face more barriers than non-underrepresented students on the path to college success. For example, first-generation students and racial and ethnic minority students enrolled in predominantly White institutions often experience a cultural mismatch between their campus lives and their off-campus lives, which can be detrimental to their persistence (Stephens, Fryberg, Markus, Johnson, \& Covarrubias, 2012). In addition, students from low-income households not only receive fewer financial supports from parents, but also often have family responsibilities that substantially limit their capacity to devote adequate time and attention to academic learning and schoolwork (Bridges, Kinzie, Nelson Laird, $\&$ Kuh, 2008). In general, compared to their non-underrepresented students, underrepresented students are less prepared for college, possess less knowledge about postsecondary education, and lack the cultural capital needed to navigate the higher education environment (Levin, Belfield, Muennig, \& Rouse, 2007). These conditions can make underrepresented students' freshman-year experience especially challenging, putting their college adjustment and likelihood of re-enrollment and persistence in jeopardy.

Several theories of college student development provide insights into underrepresented students' experiences. For example, one set of theories suggests that minority students are more likely than majority students to experience family conflicts and instability in their familial relationships, resulting in general feelings of instability during their college (Bahrassa, Syed, Su, \& Lee, 2011; Nelson, Bahrassa, Syed, \& Lee, 2015; Syed \& Mitchell, 2013). By providing minority students with meaningful, relevant, and impactful experiences during their first college years, students can develop a protective sheath that helps build the resiliency needed to adjust to and thrive in their new university environment (Syed \& Mitchell, 2013).

The interactions that service-learning encourages often engage students with individuals and groups from different cultural, racial, ethnic, and family backgrounds. For underrepresented students, such experiences can be appealing in that they provide opportunities to interact with issues that affect diverse communities, including their own. In well-designed service-learning programs, students can develop and practice civic responsibility and intercultural skills in diverse settings by experiencing new ways of learning (Faletta, Meier, \& Balderas, 2016). For example, Stavrianopoulos (2008) found that a group of 25 entering freshmen, mostly first-generation and from lower middle class families, reported that service-learning experiences in the first year fostered their understanding of course materials, personal and moral growth, a sense of responsibility toward other members of society, and close bonds among students. Despite the study's relatively small sample size, Stavrianopoulos concluded that the service-learning component had a positive influence on underrepresented students' perceptions of their learning experiences and that it contributed positively to the students' overall academic and social adjustment.

There is an emerging literature that points to differential effects of service-learning for underrepresented students, when compared to non-underrepresented peers. For example, in a study of the influence of race on service-learning outcomes, Mungo (2017) found that students' race did not moderate the association between service-learning participation and graduation; rather, service-learning increased the graduation rate for all students regardless of their race. In another study of a student cohort that entered a university in the same year, service-learning participation was found to be positively related to underrepresented students' cumulative GPAs by the end of the fourth year as well as their graduation within 
four years (Song et al., 2017). More studies that explore the impact of underrepresented students' servicelearning involvement and when they participate in service-learning would help build a better understanding of the possible association (or associations) between underrepresented students' learning outcomes and their participation in high-impact practices that promote college success and global workforce development (Finley \& McNair, 2013).

\section{The Present Study}

The research on service-learning has long been criticized for conducting too few randomized, controlled studies, using small sample sizes, lacking comparison groups, and utilizing non-standardized and nonvalidated instruments (Clayton, Bringle, \& Hatcher, 2013; Furco, 2003). Commonly noted limitations of the extant service-learning research include the lack of randomized experimental designs, reliance on nonstandardized and non-validated instruments, and the overuse of post-only assessments to assess servicelearning's impact on student development (Gallini \& Moely, 2003). Clayton et al. (2013) wrote:

Often-cited limitations in the broader research on service-learning include the following: limited generalizability of findings due to small sample sizes; inadequate number of longitudinal studies, which allow for a fuller assessment of change over substantial periods of time; heavy reliance on data based on unsubstantiated self-reports; lack of replication of high-quality studies; limited ability to aggregate data due to wide variation in service-learning purposes and practices across programs and sites. (p. 460)

There are many variables to consider when assessing the impact of service-learning on students' college success. Students' demographic backgrounds, previous academic performance, and academic preparedness, for example, all strongly predict students' college retention and degree completion (Astin \& Oseguera, 2005; Crisp \& Nora, 2010; DeAngelo, Franke, Hurtado, Pryor, \& Tran, 2011; Pike, Hansen, \& Childress, 2014). The complex factors that contribute to college success make it challenging to isolate the effect of a solitary intervention such as service-learning.

Although randomized control trials are considered by federal agencies as the "gold standard" for drawing causal associations in educational research (Donaldson, Christie, \& Mark, 2015), the randomization of students to the service-learning treatment was not achievable in this study because students largely self-selected courses with or without service-learning components. Student self-selection into courses that contain service-learning produces selection bias, which can limit researchers' capacities to attribute observed outcomes to the treatment under investigation (Rama, Ravenscroft, Wolcott, \& Zlotkowski, 2000).

To respond to this limitation, we applied propensity score matching (PSM), a statistical technique that enables researchers to match participants in the treatment group with participants in the control group in ways that account for self-selection bias. With PSM, individual participants are matched based on a set of key characteristics that exist before any participant receives the treatment. The premise of PSM is that by matching individuals on characteristics that could account for differences between groups and thereby controlling for those characteristics, two groups can be created that will have the same likelihood of selecting or not selecting courses that contain service-learning (Pan \& Bai, 2015). Therefore, rather than comparing the results of the overall treatment group with the overall comparison group, the analysis compares two matched group. Along with minimizing effects of self-selection bias, other advantages of the PSM approach include minimizing the effect of pre-existing differences in student characteristics as well as optimizing the equivalence of the treatment and comparison groups.

The present study aimed to investigate how first-year participation in service-learning courses related to two independent cohorts of undergraduate students' academic outcomes, retention, and graduation over a period of five or six college years. To this end, the study makes several contributions to the servicelearning literature. First, it furthers understanding of service-learning's potential for enhancing the success of underrepresented students, who, because of the academic and social barriers they face, might benefit more from participating in a high-impact practice (Kuh et al., 2011). Second, it expands the collective 
6 | International Journal of Research on Service-Learning and Community Engagement

understanding of the role of service-learning courses by examining if early participation in service-learning (i.e., in the first college year) makes a difference with regard to students' (especially underrepresented students') long-term educational success. Third, through the application of the PSM technique, we formed two equivalent student groups (service-learning treatment and non- service-learning comparison) that shared the same key characteristics, thus improving the precision of estimating the effects of servicelearning. This approach addresses some of the existing criticism regarding the lack of scientific rigor and empiricism in studies of service-learning. Fourth, in comparison to the majority of service-learning studies, which tend to draw conclusions based on small samples (Clayton et al., 2013), this study employed large sample size (i.e., more than 1,000 students in each comparison and treatment group for each cohort). Lastly, by repeating the design and analyses for two independent cohorts of students, the study incorporated replication, which addresses another limitation (i.e., lack of replication) among current service-learning studies.

Guided by these purposes, the research questions of the present study were as follows:

1. Is participation in at least one service-learning course during the first year of college predictive of future cumulative GPAs and credits earned for (a) all undergraduate students and (b) students from underrepresented groups?

2. Is participation in at least one service-learning course during the first year of college predictive of fall-to-fall re-enrollment for (a) all undergraduate students and (b) students from underrepresented groups?

3. Is participation in at least one service-learning course during the first year of college predictive of four-, five-, or six-year graduation rates for (a) all undergraduate students and (b) students from underrepresented groups?

\section{Data and Samples}

\section{Method}

Student demographic and course participation data were drawn from an existing database held by an institutional research office at a large Midwestern research university. Information was provided regarding the cohort of students who enrolled at the university for the first time in either fall $2011(\mathrm{~N}=5,368)$ or fall $2012(\mathrm{~N}=5,514)$ as new freshmen. Each cohort was analyzed separately to reduce threats to external validity. All students were tracked from their first admission term to their last enrolled term, up through the fall of 2017. In each year, the university offered between 120 and 130 credit-bearing courses with servicelearning components. For these courses, partnerships were maintained with more than 300 nonprofit organizations in and around the surrounding communities to provide sites for students' service experiences. In service-learning classes, community engagement became part of the coursework and served as a source of information to enrich course materials and discussions. At this institution, only those courses that met the following minimum requirements were considered and counted as service-learning courses: (1) students performed a minimum of 3 hours per week of service-learning related activity in a semester; and (2) students were provided opportunities for critical reflection on their service-learning experience. However, in addition to these minimum requirements, most service-learning courses at the institution incorporated other best-practice principles found in the service-learning literature.

Within the 2011 cohort, $52 \%$ of the freshmen at entry were female, with an average age of 18.14 $(S D=.49)$ years. The racial breakdown of the students was $76 \%$ White, $16 \%$ Asian, $4 \%$ Black, 3\% Hispanic, and $2 \%$ other races. About $48 \%(n=2,564)$ of the students in this sample were considered to be historically underrepresented, by being identified as a racial/ethnic minority $(25 \%)$, first-generation $(26 \%)$, and/or Pell eligible (22\%). Among the full sample, 1,047 took their first service-learning course(s) in their freshman year, while the potential comparison group consisted of 2,125 students who did not take a service-learning course during their college years.

Within the 2012 cohort, $51 \%$ of the freshmen at entry were female, with an average age of 18.12 $(S D=.46)$ years. The racial breakdown of the students was $75 \%$ White, $16 \%$ Asian, $4 \%$ Black, 3\% Hispanic, and $3 \%$ other races. About $45 \%(n=2,505)$ of the students in this sample were considered historically 
underrepresented; they were identified as racial and/or ethnic minorities (26\%), first-generation college attendees (25\%), and/or Pell eligible (27\%). Among the full sample, 1,055 took at least one service-learning course in their first year, while the potential comparison group consisted of 2,307 students who did not take a service-learning course during their college years.

\section{Outcome Measures}

We examined whether initial service-learning participation in the first year was related to four types of college outcomes. First, we calculated end-of-year cumulative GPAs (on the standard 4-point scale) to capture students' academic achievement across each of their college years up to six years for the 2011 cohort and five years for the 2012 cohort (through 2017). Second, we calculated the total credits students earned by the end of each year through the sixth year for the 2011 cohort and through the fifth year for the 2012 cohort. For any given year, cumulative GPAs and credits earned were continuous variables and based on all previous courses taken while enrolled. The third outcome was the rate of student retention after the first year by verifying students' enrollment status (i.e., registered as a full-time graduate student) in successive fall terms, taking into account students who had graduated in previous years. The students were coded as 1 if they were enrolled in the fall term; otherwise, they were coded as 0 . The fourth outcome we assessed was the graduation rate within four, five, and six years by verifying students' graduation status $(1=$ Graduated, $0=$ Not graduated). The retention and graduation statuses were treated as dichotomous variables. Data from students with freshman status in both 2011 and 2012 were used to calculate the graduation rate within four and five years. Given that our data gathering occurred only through the summer of 2017, the six-year graduation comparison between service-learning and non-service-learning students was limited to data from the 2011 cohort.

\section{Data Analysis}

\section{Propensity score matching (PSM)}

Prior to beginning our analysis, we used PSM to match students who took their first service-learning course(s) in their first college year (i.e., during 2011-2012 or 2012-2013) with students who did not take any service-learning course at any time during their college years. The matching model included a set of covariates that are conceptually associated with student college outcomes, including previous academic performance (i.e., ACT composite scores) and personal demographic variables (i.e., gender, age, race and ethnicity, first-generation status, Pell grant eligibility, U.S. citizenship, and international student status). Accounting for these covariates, a propensity score was generated for each observation; the propensity score statistically calculated a student's probability (i.e., likelihood) of taking service-learning course(s) during the first year. For each of the students in the two study cohorts (students first enrolling at the university in 2011 and students first enrolling in 2012), we determined (using institutional data) whether the student participated or did not participate in service-learning during the first year of enrollment. To ensure that service-learning participation was unique to the sample, students who did not participate in service-learning in their first year but who participated in service-learning in subsequent years were removed from possible inclusion in the comparison group. This resulted in two groups for each cohort: students who participated in service-learning during the first year (treatment group) and students who did not participate in any service-learning during their time at the university (comparison group). Using the propensity scores, students in the treatment group were individually matched with students in the comparison group through nearest-neighbor one-to-one matching without replacement (Austin, 2011), with a specified caliper distance of .20 (Rosenbaum \& Rubin, 1985).

The balance diagnostics conducted after matching students and forming the two groups indicated that the treatment and comparison groups were sufficiently well-matched with respect to their background characteristics and previous academic achievement. To determine if the resulting matched groups were equivalent, we estimated the standardized mean differences between groups on the set of covariates (Pattanyak, 2015). Students who took at least one service-learning course during the first academic year 
8 | International Journal of Research on Service-Learning and Community Engagement

were not systematically or qualitatively different from non-service-learning students in any of the baseline covariates (i.e., < .25 standardized mean differences; Austin, 2011). Standards of the U.S. Department of Education's What Works Clearinghouse (2017) recommend including as covariates variables that still have between-group differences that are larger than a .05 standardized mean after matching. To meet this requirement, we controlled for gender in the subsequent analysis of the fall 2012 cohort sample given that the standardized mean differences between the groups was .06 after matching; no covariates needed to be controlled in the analysis of the fall 2011 cohort.

\section{Regression analyses}

Using the matched sample selected through PSM, we performed linear regression analyses to examine the association between first-year service-learning course participation and students' cumulative GPAs and credits earned by the end of each academic year. GPAs and credits earned served as continuous dependent variables. Service-learning participation status was the independent variable (gender was included as a covariate for the 2012 cohort). Logistic regression analyses were performed to determine if first-year participation in a service-learning course (or courses) was predictive of retention and graduation rates. Retention and graduation status were dichotomous dependent variables. First-year service-learning was the independent variable (gender was a covariate for the 2012 cohort). Parallel analyses were conducted separately for the full sample and for the underrepresented group of each cohort. All analyses were conducted using SPSS (version 24).

\section{Results}

Descriptive statistics for the academic outcomes of the service-learning and non-service-learning groups are presented in Table 1. Results from the regression analyses of outcomes by academic years are presented in Table 2 (linear regression analyses of the GPAs and credits earned) and Table 3 (logistic regression analyses of the retention and graduation rates). Since we focused on investigating the effect of servicelearning participation, we do not report here the results for the controlled covariate (i.e., gender in the analysis of 2012 cohort). The following subsections elaborate the main findings for each cohort.

\section{The 2011 Cohort}

\section{GPAs and credits earned}

Students who took their first service-learning course (or courses) during the first year achieved higher cumulative GPAs than students who did not take service-learning courses throughout their college years. The same pattern appeared for the underrepresented group. Regarding the total credits earned, first-year service-learning participation was associated with more credits earned by the end of the third academic year for the full sample $(B=3.24, p=.005)$ and the underrepresented groups $(B=4.09, p=.019)$ but not in other years. Even though some findings were not significant, in all instances, the service-learning group earned more credits than the comparison group.

\section{Retention and graduation rates}

First-year service-learning participation was positively associated with retention rates in the second, third, and fourth years for the overall sample. For the underrepresented students, it was significantly associated with a higher likelihood of re-enrollment only in the second year $(B=.53, p=.042, O R=1.70)$ even though the magnitude of differences was similar to that found for the full sample. Regarding the graduation rate, first-year service-learning participation was associated with a higher likelihood of graduation within four $(B=.40, p<.001, O R=1.48)$, five $(B=.37, p=.005, O R=1.45)$ and six years $(B=.36, p=.011, O R=1.43)$. Underrepresented students who took a service-learning course (or courses) during the first year were more likely to graduate within four years than underrepresented students who did not participate in servicelearning during their college years $(B=.32, p=.027, O R=1.37)$. 
Table 1. Descriptive Statistics of Outcomes by Students Who Took the First Service-Learning Course(s) in the First Year and Those Who Never Did During the College Years

\begin{tabular}{|c|c|c|c|c|c|c|c|c|}
\hline \multirow{3}{*}{ Outcomes } & \multicolumn{4}{|c|}{2011 Cohort } & \multicolumn{4}{|c|}{2012 Cohort } \\
\hline & \multicolumn{2}{|c|}{ Full sample } & \multicolumn{2}{|c|}{ Underrepresented students } & \multicolumn{2}{|c|}{ Full sample } & \multicolumn{2}{|c|}{ Underrepresented students } \\
\hline & $\begin{array}{l}\text { Non-SL } \\
(\mathrm{n}=922)\end{array}$ & $\begin{array}{c}\text { SL } \\
(\mathrm{n}=922)\end{array}$ & $\begin{array}{c}\text { Non-SL } \\
(\mathrm{n}=454)\end{array}$ & $\begin{array}{c}\text { SL } \\
(n=431)\end{array}$ & $\begin{array}{l}\text { Non-SL } \\
(\mathrm{n}=907)\end{array}$ & $\begin{array}{c}\text { SL } \\
(n=907)\end{array}$ & $\begin{array}{l}\text { Non-SL } \\
(\mathrm{n}=427)\end{array}$ & $\begin{array}{c}\text { SL } \\
(n=419)\end{array}$ \\
\hline \multicolumn{9}{|l|}{$G P A s$} \\
\hline EOY 1 & $3.20(.54)$ & $3.31(.45)$ & $3.11(.58)$ & $3.22(.47)$ & $3.23(.52)$ & $3.30(.46)$ & $3.16(.50)$ & $3.23(.49)$ \\
\hline EOY 2 & $3.16(.55)$ & $3.28(.46)$ & $3.08(.60)$ & $3.19(.47)$ & $3.19(.53)$ & $3.26(.49)$ & $3.12(.53)$ & $3.16(.53)$ \\
\hline EOY 3 & $3.16(.56)$ & $3.28(.46)$ & $3.07(.60)$ & $3.19(.49)$ & $3.19(.53)$ & $3.26(.49)$ & $3.12(.53)$ & $3.16(.55)$ \\
\hline EOY 4 & $3.15(.58)$ & $3.28(.48)$ & $3.07(.61)$ & $3.18(.52)$ & $3.20(.53)$ & $3.27(.51)$ & $3.13(.53)$ & $3.16(.56)$ \\
\hline EOY 5 & $3.17(.59)$ & $3.28(.51)$ & $3.06(.61)$ & $3.18(.52)$ & $3.21(.53)$ & $3.27(.51)$ & $3.14(.53)$ & $3.17(.56)$ \\
\hline EOY 6 & $3.15(.58)$ & $3.28(.49)$ & $3.06(.61)$ & $3.18(.52)$ & i & i & i & i \\
\hline \multicolumn{9}{|c|}{ Credits Earned } \\
\hline \multirow[t]{2}{*}{ EOY 1} & 49.99 & 49.64 & 49.58 & 50.23 & 51.78 & 50.81 & 52.25 & 51.97 \\
\hline & $(18.05)$ & $(17.32)$ & $(18.28)$ & $(17.66)$ & $(17.76)$ & $(17.38)$ & $(18.76)$ & $(18.55)$ \\
\hline \multirow[t]{2}{*}{ EOY 2} & 79.25 & 80.26 & 78.11 & 80.10 & 81.09 & 81.12 & 80.51 & 81.18 \\
\hline & $(20.68)$ & $(19.35)$ & $(21.38)$ & $(20.01)$ & (19.98) & (19.50) & $(21.53)$ & $(21.30)$ \\
\hline \multirow[t]{2}{*}{ EOY 3} & 105.55 & 108.71 & 103.81 & 107.91 & 107.09 & 108.06 & 105.24 & 107.83 \\
\hline & $(26.05)$ & $(22.89)$ & $(27.36)$ & $(24.13)$ & $(25.39)$ & $(23.53)$ & $(27.87)$ & $(26.15)$ \\
\hline \multirow[t]{2}{*}{ EOY 4} & 112.84 & 113.81 & 111.23 & 113.36 & 127.27 & 129.14 & 124.18 & 127.25 \\
\hline & $(28.81)$ & $(26.51)$ & $(29.78)$ & $(28.83)$ & $(32.42)$ & $(31.37)$ & $(35.66)$ & $(32.30)$ \\
\hline \multirow[t]{2}{*}{ EOY 5} & 114.13 & 114.64 & 112.38 & 114.40 & 130.53 & 131.47 & 127.79 & 128.38 \\
\hline & $(29.21)$ & $(27.10)$ & $(30.07)$ & $(29.49)$ & $(32.86)$ & $(31.60)$ & $(36.54)$ & $(34.77)$ \\
\hline \multirow[t]{2}{*}{ EOY 6} & 114.47 & 114.89 & 112.74 & 114.82 & / & / & 1 & I \\
\hline & $(29.25)$ & $(27.11)$ & $(30.15)$ & $(29.56)$ & & & & \\
\hline \multicolumn{9}{|l|}{ Retention } \\
\hline Year 2 & $92.1 \%$ & $95.1 \%$ & $90.5 \%$ & $94.2 \%$ & $91.8 \%$ & $94.2 \%$ & $89.9 \%$ & $91.6 \%$ \\
\hline Year 3 & $88.9 \%$ & $92.7 \%$ & $87.4 \%$ & $90.6 \%$ & $88.9 \%$ & $91.7 \%$ & $84.7 \%$ & $89.5 \%$ \\
\hline Year 4 & $86.8 \%$ & $90.6 \%$ & $83.7 \%$ & $87.8 \%$ & $86.0 \%$ & $89.1 \%$ & $80.9 \%$ & $84.1 \%$ \\
\hline \multicolumn{9}{|l|}{ Graduation } \\
\hline 4-year & $65.9 \%$ & $74.2 \%$ & $62.6 \%$ & $69.6 \%$ & $70.0 \%$ & $74.2 \%$ & $64.9 \%$ & $71.4 \%$ \\
\hline 5-year & $82.2 \%$ & $87.0 \%$ & $79.3 \%$ & $83.1 \%$ & $82.7 \%$ & $86.3 \%$ & $78.9 \%$ & $82.1 \%$ \\
\hline 6-year & $85.6 \%$ & $89.5 \%$ & $82.6 \%$ & $86.3 \%$ & / & / & & \\
\hline
\end{tabular}

Note. Means and standard deviations for cumulative GPAs and units earned; percentages within group for enrollment and graduation status; $\mathrm{EOY}=$ End of Year. 
Table 2. Linear Regression Analysis of the Association between First-Year Service-Learning and Cumulative GPAs and Total Credits Earned

\begin{tabular}{|c|c|c|c|c|c|c|c|c|c|c|c|c|c|c|c|c|}
\hline \multirow{3}{*}{ Outcomes } & \multicolumn{8}{|c|}{2011 Cohort } & \multicolumn{8}{|c|}{2012 Cohort } \\
\hline & \multicolumn{4}{|c|}{ Full sample } & \multicolumn{4}{|c|}{ Underrepresented students } & \multicolumn{4}{|c|}{ Full sample } & \multicolumn{4}{|c|}{ Underrepresented students } \\
\hline & $\mathrm{B}$ & SE & $p$ & $?^{2}$ & $\mathrm{~B}$ & SE & $p$ & $?^{2}$ & $\mathrm{~B}$ & SE & $p$ & $R^{2}$ & $\mathrm{~B}$ & SE & $p$ & $R^{2}$ \\
\hline \multicolumn{17}{|c|}{ Cumulative GPAs } \\
\hline EOY 1 & .11 & .0 & $<.001$ & .012 & .10 & .04 & .004 & .010 & .07 & .02 & .001 & .006 & .07 & .03 & .036 & .005 \\
\hline EOY 2 & .12 & .02 & $<.001 *$ & .014 & .12 & .04 & .002 & .011 & .07 & .02 & .004 & .005 & .05 & .04 & .144 & .003 \\
\hline EOY 3 & .12 & .02 & $<.001^{*}$ & .014 & .11 & .04 & .002 & .011 & .08 & .02 & .001 & .006 & .05 & .04 & .141 & .003 \\
\hline EOY 4 & .13 & .03 & $<.001 *$ & .014 & .11 & .04 & .003 & .010 & .07 & .02 & .003 & .005 & .04 & .04 & .244 & .002 \\
\hline EOY 5 & .13 & .03 & $<.001 *$ & .014 & .12 & .04 & .003 & .010 & .07 & .02 & .004 & .005 & .04 & .04 & .289 & .001 \\
\hline EOY 6 & .13 & .03 & $<.001 *$ & .014 & .11 & .04 & .003 & .010 & / & / & / & l & / & / & l & / \\
\hline \multicolumn{17}{|c|}{ Cumulative Units Earned } \\
\hline EOY 1 & -.35 & .82 & .671 & $<.00$ & .64 & 1.2 & .593 & $<.00$ & -.97 & .83 & .240 & .001 & -.17 & 1.2 & .893 & $<.001$ \\
\hline EOY 2 & 1.0 & .93 & .279 & .001 & 1.9 & 1.3 & .153 & .002 & .06 & .93 & .849 & $<.00$ & .87 & 1.4 & .555 & $<.001$ \\
\hline EOY 3 & 3.1 & 1.1 & $.006^{*}$ & .004 & 4.0 & 1.7 & .019 & .006 & 2.0 & 1.1 & .079 & .002 & 2.8 & 1.8 & .123 & .003 \\
\hline EOY 4 & .97 & 1.2 & .452 & $<.00$ & 2.1 & 1.9 & .280 & .001 & 1.8 & 1.5 & .207 & $<.00$ & 3.2 & 2.3 & .169 & .002 \\
\hline EOY 5 & .52 & 1.3 & .693 & $<.00$ & 2.0 & 2.0 & .313 & .001 & .93 & 1.5 & .541 & $<.00$ & 1.1 & 2.4 & .594 & $<.001$ \\
\hline EOY 6 & .42 & 1.3 & .748 & $<.00$ & 2.0 & 2.0 & .301 & .001 & 1 & 1 & I & I & 1 & 1 & I & I \\
\hline
\end{tabular}

Note. ${ }^{*}$ indicates significance, which is $\mathrm{p}<.05$; controlling for gender for the 2012 cohort; EOY = End of Year. 
Table 3. Logistic Regression Analysis of the Association between First-Year Service-Learning and the Likelihoods of Retention and Graduation

\begin{tabular}{|c|c|c|c|c|c|c|c|c|c|c|c|c|c|c|c|c|}
\hline \multirow[t]{3}{*}{ Outcomes } & \multicolumn{8}{|c|}{2011 Cohort } & \multicolumn{8}{|c|}{2012 Cohort } \\
\hline & \multicolumn{4}{|c|}{ Full sample } & \multicolumn{4}{|c|}{ Underrepresented students } & \multicolumn{4}{|c|}{ Full sample } & \multicolumn{4}{|c|}{ Underrepresented students } \\
\hline & $\mathrm{B}$ & $\mathrm{SE}$ & $p$ & OR & $\mathrm{B}$ & SE & $p$ & OR & $\mathrm{B}$ & $\mathrm{SE}$ & $p$ & OR & $\mathrm{B}$ & SE & $p$ & OR \\
\hline \multicolumn{17}{|l|}{ Retention } \\
\hline Year 2 & .52 & .20 & $.008 *$ & 1.68 & .53 & .26 & $.042 *$ & 1.70 & .37 & .19 & $.049 *$ & 1.45 & .21 & .24 & .389 & 1.23 \\
\hline Year 3 & .47 & .17 & $.005 *$ & 1.59 & .34 & .22 & .124 & 1.40 & .33 & .16 & $.038 *$ & 1.40 & .43 & .21 & $.039 *$ & 1.54 \\
\hline Year 4 & .38 & .16 & $.014^{*}$ & 1.46 & .34 & .20 & .096 & 1.40 & .30 & .15 & $.043 *$ & 1.35 & .22 & .19 & .251 & 1.25 \\
\hline \multicolumn{17}{|l|}{ Graduation } \\
\hline Year 4 & .40 & .10 & $<.001 *$ & 1.48 & .32 & .14 & $.027 *$ & 1.37 & .25 & .11 & $.020^{*}$ & 1.28 & .30 & .15 & $.043 *$ & 1.35 \\
\hline Year 5 & .37 & .13 & $.005 *$ & 1.45 & .25 & .17 & .153 & 1.28 & .30 & .13 & $.025^{*}$ & 1.34 & .20 & .17 & .244 & 1.23 \\
\hline Year 6 & .36 & .14 & $.011 *$ & 1.43 & .28 & .19 & .129 & 1.33 & 1 & / & I & I & I & I & 1 & I \\
\hline
\end{tabular}

Note. $*$ indicates significance, which is $\mathrm{p}<.05 ; \mathrm{OR}=$ Odds Ratio; controlling for gender for the 2012 cohort. 


\section{The 2012 Cohort}

\section{GPAs and credits earned}

Similar to the 2011 cohort, first-year service-learning students outperformed non-service-learning students throughout their college years in cumulative GPAs. Underrepresented students who took a service-learning course (or courses) during their first year had significantly higher cumulative GPAs than their non-servicelearning peers at the end of the first year $(B=.07, p=.036)$ but not in the subsequent years even though the direction of difference continued to favor students taking service-learning courses. Taking a servicelearning course (or courses) during the first academic year was not related to cumulative credits earned in any college year for either the full sample or the underrepresented group.

\section{Retention and graduation rates}

Consistent with the 2011 cohort, students in the full 2012 cohort sample who took a service-learning course (or courses) during the first year were more likely to re-enroll in the following year. Underrepresented students who participated in a service-learning course (or courses) by the end of the first year were more likely to be enrolled in the third year $(B=.43, p=.039, O R=1.54)$ than underrepresented students who did not participate in service-learning. In addition, consistent with the findings of the 2011 cohort, first-year service-learning participation among students in the 2012 cohort was associated with higher four-year $(B=.25, p=.020, O R=1.28)$ and five-year $(B=.30, p=.025, O R=1.34)$ graduation rates. The underrepresented group was also more likely to graduate within four years $(B=.30, p=.043, O R=1.35)$. Even though some findings were not significant, in all instances, the service-learning group scores were more favorable than the comparison group.

\section{Discussion}

This study investigated whether enrolling in a service-learning course (or courses) in the first year of college was related to students' (1) cumulative GPAs on a year-to-year basis, (2) total credits earned by the end of each academic year, (3) retention rates in the second and following years (until fall 2017), and (4) graduation rates within four, five, and six years. Separate analyses were performed for the full selected student sample and the underrepresented group of two cohorts. We sought to build on and strengthen prior research by addressing the limitation of self-selection bias using propensity score matching (PSM), replicating the study through the use of two independent cohorts, and incorporating relatively large sample sizes in our investigation. The PSM matching method allowed us to assess the impact of key baseline observed covariates on student outcomes by identifying and statistically controlling for particular characteristics that likely distinguished students who chose service-learning courses from those who did not, thus strengthening the equivalence of the treatment and control groups.

Our study findings revealed that enrollment in a service-learning course (or courses) in the first year facilitated participating students' year-to-year cumulative GPA. However, with a few exceptions, it did not have a bearing on the number of credits students earned. Consistent with previous empirical findings on the positive effects of service-learning on college student retention (Bringle et al., 2010; Reed, Rosenberg, Staham, \& Rosing, 2015), our study found that participating in a service-learning course (or courses) during the first year increased the likelihood of students' retention in the second year for both cohorts; however, we also found that this positive association continued beyond students' second year in college. In addition, in line with two previous studies on service-learning and college student graduation (Lockeman \& Pelco, 2013; Yue \& Hart, 2017), our study found that participation in service-learning during the first year significantly predicted the likelihood of graduating within four, five, and six years. For underrepresented students, our study found some, though inconsistent, benefits of taking a service-learning course (or courses) during the first year related to retention and graduation among students from historically underrepresented backgrounds. Further research on the role of early-years participation in service-learning among students from underrepresented backgrounds is warranted. 
From the extant literature on service-learning, we extract several explanations for the positive associations we found between early participation in service-learning and college retention and graduation for the full sample. First, as we hypothesized, it is likely that through service-learning, students experience more peer interaction, faculty interaction, and active learning compared to students in other courses (Bringle et al., 2010). Such academic engagement with peers and faculty during the first college year has been associated with greater student retention (DeAngelo, 2014; Vogelgesang, Ikeda, Gilmartin, \& Keup, 2002). In addition, for underrepresented students, increased engagement and interaction have been found to reduce the cultural mismatch they often experience in college; such experiences highlight interdependent norms that are consistent with their personal experiences in families and home communities (Lockeman \& Pelco, 2013). These kinds of interactions are especially important for enhancing all students', but especially underrepresented students', sense of belonging (Hurtado, 2007).

In addition, students with better academic preparation in early college years have been found to attain more cultural capital, and they are more likely to enroll in more service-learning classes and other educationally purposeful forms of engagement that potentially enhance students' success (Kuh, 2008). In turn, taking more service-learning courses during the undergraduate years may be related to a higher likelihood of degree completion than for students who do not enroll in any service-learning course (Lockeman \& Pelco, 2013; Yue \& Hart, 2017). Early community service experiences have also been found to encourage involvement in future community service (Preis \& Fenzel, 2003). The higher quality educational experiences attained in service-learning courses can be deepened in subsequent courses, which may create additive effects and ultimately motivate students to more fully engage academically, socially, and civically.

For underrepresented students, who are at a greater risk than non-underrepresented students of leaving the institution before they complete their college education (Hurtado, 2007), our study found that first-year service-learning participation is beneficial to their educational advancement and success. Specifically, when compared to underrepresented students who did not participate in service-learning, underrepresented students who took a service-learning course during their first year of college graduated at significantly higher rates within four years and were more likely to be retained in college in the second year for the 2011 cohort and in the third year for the 2012 cohort. This finding supports some previous qualitative and quantitative studies, which have found that underserved students (including first-generation, transfer, and racial and ethnic minority) who were exposed to one or more high-impact practices reported deeper engagement in learning and higher personal gains than first-generation students who were not exposed to a high-impact practice (Finley \& McNair, 2013).

In contrast to the consistent findings for the full sample, the findings for underrepresented students were less consistent. While there was a positive association between first-year service-learning participation and higher retention for underrepresented students, we are not able to explain with any certainty why the benefits of service-learning did not manifest for any of the subsequent years of underrepresented students' enrollments. One possible explanation is that the differences in benefits found across enrollment years are due to the lower power of the analysis that resulted from the smaller sample size of the underrepresented groups (when compared to the size of the overall sample). The differences across years may also be due to the barriers that underrepresented students often face, such as limited time or money, competing priorities, and a lack of social support, which get in the way of participating in service-learning over time and/or engaging fully with college (Finley \& McNair, 2013). For instance, studies have found that compared to students with no financial concerns, first-year students with major financial concerns are less likely to have high levels of academic engagement, are less likely to re-enroll in college in their second year (DeAngelo, 2014; Herzog, 2005), and are less likely to graduate (Lockeman \& Pelco, 2013). Thus, further research is needed to understand how service-learning participation might affect underrepresented students' retention throughout their college years. 


\section{Limitations}

While the findings of this study provide additional evidence of how a high-impact practice (i.e., servicelearning) contributes to college students' educational achievement, retention, and graduation, and while the study sought to address some of the longstanding criticisms regarding the scientific rigor of service-learning research, the study did have several limitations. First, it is not known how representative the students from this institution are of the general college student population. To strengthen the confidence in our findings, we intentionally replicated the study by conducting independent analyses of two separate cohorts of students (2011 and 2012 college entrance) to assess the consistency in findings between two cohort investigations. Nevertheless, both cohorts were from the same relatively selective Midwestern research university, which likely attracts a student body that differs from the student bodies at higher education institutions in other parts of the country and institutions that have different institutional profiles (e.g., liberal arts college, community college, etc.). Consequently, without the ability to account for the uniqueness or commonality of this university's institutional characteristics (e.g., student enrollment, school type, and nature of academic programs), the generalizability of our results and conclusions likely may be limited to students and institutions that have a similar profile as those of our sample, at best. We recommend that the study be replicated by applying the same study design and methods across more diverse cohorts and at institutions with varying characteristics.

Second, there were significant variations in the number and type of service-learning courses available to students at the institution. The course content and practices of the service-learning experiences varied substantially across academic disciplines. Grouping students by colleges could serve as a way to control variations in service-learning courses. However, the sample sizes within each college were not robust enough to allow for college-level analyses. In addition, the lower statistical power that would result from the substantially smaller sample sizes of students grouped by college might diminish the prevalent positive effects of service-learning in colleges that have smaller enrollments.

Third, the measure of the treatment (i.e., service-learning) was limited. Even though the study found encouraging effects of service-learning on institutional outcomes, our study was not able to capture the extent to which service-learning was implemented with fidelity across courses. It is likely that across students' service-learning experiences, there were variations in the levels of faculty involvement, amount of student investment in the service-learning experience, and the nature of the service activities performed (e.g., direct versus indirect service). We attempted to address this limitation by analyzing archival data from a survey that had been administered to all college students and that explored the particulars of students' service-learning experiences and their levels of academic involvement. Yet, the administrations of the survey resulted in generally low response rates $(15 \%-20 \%)$. Consequently, the survey data were not representative of the institution's broader student population. Moreover, the survey itself was limited regarding the data needed to assess the quality of implementation of the treatment (i.e., the survey did not track the service that students' actually performed or provided, or other programmatic details regarding the service-learning experience).

A fourth limitation of our study relates to potential variations in outcome measures for which we could not account. For instance, students with a major in science may have relatively lower GPAs than students in social science and the humanities, or college credits that students might have completed while a high school student (or before their college admission year) are not included when examining students' academic progress. These non-institutional academic credits and GPAs do figure into the calculations of the number of courses and credits students complete and of students' time to graduation. Although we did not find differences between the groups in credits brought into the university, the institutional data we used regarding total credits earned and semesters to graduation may not have represented students' annual academic progress with perfect accuracy, especially given the fact that the academic timetables for students who took college units before actually enrolling at the university may be different (e.g., students could theoretically finish college early).

A final limitation to note is that this study was not able to account for the potential behavioral and attitudinal differences between the service-learning students and non-service-learning students. For 
instance, the likelihood of taking a service-learning course might be related to students' social capital, adjustment to college, and self-awareness. The rationale of propensity score matching is that to the extent possible potentially important variables should be included in the model when generating propensity scores in order to eliminate any selection bias (Austin, Mamdani, Stukel, Anderson, \& Tu., 2005). However, this study used a secondary dataset, which limited us to the variables for which data were available. The propensity score was derived using the students' background variables and previous academic achievement. These variables alone likely did not fully reflect all of the factors that influenced students' decisions to enroll in courses that contain service-learning components. The question remains as to what other variables not available in our dataset (i.e., level of faculty experience with service-learning within majors, high school service-learning experiences, work and family obligations, etc.) might have affected students' likelihood of taking a service-learning course. Future studies should consider such factors to the extent possible.

\section{Implications and Future Directions}

Previous research has suggested that the inclusion of service-learning courses in the first-year learning experience encourages college students to develop a positive attitude toward the institution and a willingness to stay (Ferguson, 2006; Zlotkowski, 2002). Positive student involvement and development during the first year of college are critical because this period represents a transitional time in which students strive to be accepted by their college community (Tinto, 2012). Enrollment in service-learning courses during the first year provides an opportunity for students to build their skills and motivation for learning and relating to other people, which supports their own development and achievement of their own goals (Ferguson, 2006). Given limited research that has examined the relationship between service-learning and first-year students' positive transition to and success during college, our study provides an important step in addressing how early service-learning participation can potentially ease students' college transition and adjustment, as well as how it prepares students for success in their later college academic work.

The findings from our study suggest that the values and knowledge transmitted through service-learning courses can prepare students for a productive college life. Participation in service-learning during the early college years has benefits to students' overall college trajectory, adding more evidence to support the claim that service-learning is a high-impact practice, one that holds promise for promoting greater college student retention (Bringle et al., 2010; Reed et al., 2015; Tinto, 2012).

Given the challenges facing first-year students, Mungo (2017) suggested making service-learning a requirement in general education courses since service-learning could help students build the skills for college success along the way. Our data suggest that universities should provide more and better servicelearning courses during the first year to put students on a promising trajectory to college success. However, making service-learning programs available for college students in their early college years is only one step. Institutions of higher education also need to carefully consider how best to integrate these experiences with other student support initiatives and programs. It is important that the first-year service-learning experience be fully integrated into the academic curriculum. A study of first-year students' participation in a college service-corps program found that the program did not fare well in promoting student academic success because college credit was not explicitly tied to assignments, and the content of the service activities was not directly connected to students' coursework (Allen, Strumbos, \& Clay, 2014). Institutions and academic programs should learn from implementation studies like this one when designing first-year service-learning courses. Given the growing diversity of the student population, is it essential that postsecondary institutions envision different possibilities for schooling, and teach and provide innovative opportunities to enhance students' overall educational experience

One important focus of our investigation was on assessing the role service-learning can play in promoting the educational success of students from historically underrepresented backgrounds. Given the findings of our study, we conclude that engaging underrepresented students in service-learning in their early college years offers much promise for furthering their academic engagement and college success (i.e., higher GPA, likelihood of re-enrollment, graduation). The systematic inclusion of service-learning in early college life is likely to enhance retention for those who, according to Mungo (2017), spend the least time 
16 | International Journal of Research on Service-Learning and Community Engagement

on campus. Studies have found that underrepresented students spend less time on campus than their nonunderrepresented student peers (Hurtado et al., 2007). One encouraging statistic is that, when compared to their White peers, students of color are more aware of and more interested in service-learning upon entering college (Christensen, Stritch, Kellough, \& Brewer, 2015), even though they may have different needs for service-learning (Pearl \& Christensen, 2017). With compelling benefits for students from different backgrounds, higher levels of participation in service-learning, especially during the early years of college, may close the gaps in college engagement and completion.

\section{Concluding Comments}

Our results suggest that students benefit from taking service-learning courses during their first year of college. Potential impacts may vary based on student backgrounds, since our findings were not as consistent for underrepresented students. Although the inconsistencies may in part reflect differences in power to detect differences with a smaller sample, the inconsistent findings across our sample calls for more research to better understand the benefits of service-learning conducted in different contexts and with students from differing backgrounds. Students' understanding of what service means and their definition of community are likely shaped by their own identity and the norms they experience within their cultures (Hernandez, Mobley, Coryell, Yu, \& Martinez, 2013). Future research is needed to examine the conditional and indirect effects of participating in service-learning for students from backgrounds. When surveying underrepresented students, researchers need to pay attention to the language used in surveys, the ways in which study variables are defined and measured, and the data analysis techniques they use in order to more fully and accurately understand the nuanced experiences of students with different backgrounds and goals.

As service-learning becomes more integral to students' overall higher education experience, it is important to gain a better understanding of the optimal time (or times) during college for students to engage in service-learning. Given the increasing diversity among America's college and university students, having curricula that incorporate service-learning can help address the multifaceted educational needs of these students. This study provides some empirical evidence for engaging students during their first year of college and suggests that such engagement can boost students' GPAs, retention, and graduation rates. As institutions continue to look for ways to better serve their first-year students and increase students' college success, the findings from this study offer support for the use of service-learning to achieve this goal.

\section{Author Note}

Wei Song, Department of Educational Psychology, University of Minnesota; Andrew Furco, Department of Organizational Leadership, Policy, and Development, University of Minnesota; Geoffrey Maruyama, Department of Educational Psychology, University of Minnesota; Isabel Lopez, Department of Educational Psychology, University of Minnesota.

\section{Correspondence}

Correspondence regarding this article should be addressed to Dr. Wei Song, Department of Educational Psychology, University of Minnesota, 250 Education Sciences, 56 East River Road, Minneapolis, MN 55455. E-mail: songx596@umn.edu

\section{References}

ACT. (2017). National collegiate retention and persistence-to-degree rates. Iowa City, IA: Author. Retrieved from http://www.act.org/content/dam/act/unsecured/documents/ Retention-Persistence-Tables-2017.pdf

Allen, D., Strumbos, D., \& Clay, J. (2014). Race, ethnicity, and service-learning: Understanding access and equity using a critical quantitative approach. In A. Traver \& Z. Katz (Eds.), Service-learning at the American community college: Theoretical and empirical perspectives ( $\mathrm{pp}$. 95-110). New York: Palgrave Macmillan. 
Astin, A. W., \& Oseguera, L. (2005). Pre-college and institutional influences on degree attainment. In A. Seidman (Ed.), College student retention: Formula for student success (pp. 245-276). Westport, CT: American Council on Education/Praeger.

Austin, P. C. (2011). An introduction to propensity score methods for reducing the effects of confounding in observational studies. Multivariate Behavioral Research, 46(3), 399-424.

Austin, P. C., Mamdani, M. M., Stukel, T. A., Anderson, G. M., \& Tu, J. V (2005). The use of the propensity score for estimating treatment effects: Administrative versus clinical data. Statistics in Medicine, 24(10), 1563-1578.

Bahrassa, N. F., Syed, M., Su, J., \& Lee, R. M. (2011). Family conflict and academic performance of first-year Asian American undergraduates. Cultural Diversity and Ethnic Minority Psychology, 17(4), 415-426.

Barbatis, P. (2010). Underprepared, Ethnically Diverse Community College Students: Factors Contributing to Persistence. Journal of Developmental Education, 33(3), 16.

Barefoot, B. (2007). Teaching to improve retention. Thomson/Wadsworth E-Seminar Series. April 3, 2007.

Bauer-Wolf, J. (2017, October). Falling behind. Inside Higher Ed.

Bridges, B. K., Kinzie, J., Nelson Laird, T. F., \& Kuh, G .D. (2008). Student engagement and student success at minority serving institutions. In M. Gasman, B. Baez, \& C. Turner (Eds.), Interdisciplinary approaches to understanding minority institutions. Albany, NY: SUNY Press.

Bringle, R. G., Hatcher, J. A., \& Muthiah, R. N. (2010). The role of service learning on the retention of first year students to second year. Michigan Journal of Community Service Learning, 16(2), 3849.

Celio, C. I., Durlak, J., \& Dymnicki, A. (2011). A meta-analysis of the impact of service-learning on students. Journal of Experiential Education, 34(2), 164-181.

Christensen, R. K., Stritch, J. M., Kellough, J. E., \& Brewer, G. A. (2015). Identifying student traits and motives to service-learn: Public service orientation among new college freshmen. Journal of Higher Education Outreach and Engagement, 19(4), 39-62.

Clayton, P. H., Bringle, R. G., \& Hatcher, J. A. (2013). Research on service-learning: Conceptual frameworks and assessments (IUPUI Series of Service-Learning Research). Greenwich: Information Age Publishing.

Crisp, G., \& Nora, A. (2010). Hispanic student success: Factors influencing the persistence and transfer decisions of Latino community college students enrolled in developmental education. Research in Higher Education, 51, 175-194.

DeAngelo, L. (2013). Programs and practices that retain students from the first to the second year: Results from a national study. In R. D. Padgett (Ed.), The first-year experience. New Directions for Institutional Research.(pp. 53-75). San Francisco, CA: Jossey-Bass.

DeAngelo, L. (2014). Programs and practices that retain students from the first to second year: Results from a national study (Special issue). New Directions for Institutional Research, 160, 53-75.

DeAngelo, L., Franke, R., Hurtado, S., Pryor, J. H., \& Tran, S. (2011). Completing college: Assessing graduation rates at four-year institutions. Los Angeles: Higher Education Research Institute, UCLA.

Donaldson, S. I., Christie, C. A. \& Mark, M. M. (2015). What counts as credible evidence in applied research and evaluation practice? Thousand Oaks, CA: Sage.

Duncheon, J. C., \& Tierney, W. G. (2014). Examining college writing readiness. The Educational Forum, $78(3), 210-230$.

Engle, J. (2007). Postsecondary access and success for first-generation college students. American Academic, 3(1), 25-48.

Engle, J., \& Tinto, V. (2008). Moving beyond access: College for low income, first-generation students. Washington, DC: The Pell Institute. Retrieved May 11, 2011, from http://www.pellinstitute.org/files/COE MovingBeyondReport Final.pdf 
18 | International Journal of Research on Service-Learning and Community Engagement

Eyler, J. S. (2000). What do we most need to know about the impact of service-learning on student learning? Michigan Journal of Community Service Learning, Special Issue 1, 11-17.

Faletta, J., Meier, J. A., \& Balderas, J. U. (2016). High-impact practices: Integrating the first-year experience with service-learning and study abroad. In K. González \& R. Frumkin (Eds.), Handbook of research on effective communication in culturally diverse classrooms (pp. 337-355). Hershey, PA: Information Science Reference.

Ferguson, A. (2006). Making the case for service-learning in first-year programs. The Vermont Connection, 27(1), 1-8.

Finley, A., \& McNair, T. (2013). Assessing underserved students' engagement in high-impact practices. Washington, DC: Association of American Colleges and Universities.

Furco, A. (2003). Issues of definition and program diversity in the study of service-learning. In S. Billig \& A. Waterman (Eds.), Studying service-learning: Innovations in education research methodology (pp. 13-33). New York: Lawrence Erlbaum Publishing.

Gallini, S., \& Moely, B. (2003). Service-learning and engagement, academic challenge, and retention. Michigan Journal of Community Service Learning, 10(1), 5-14.

Ginder, S., Kelly-Reid, J., \& Mann, F. (2015). Graduation rates for selected cohorts, 2006-11; students financial aid, academic year 2013-14; and admissions in postsecondary institutions, fall 2014 (NCES 2015- 181). Washington, DC: U.S. Department of Education, National Center for Education Statistics. Retrieved from https://nces.ed.gov/pubs2015/2015181.pdf

Haskins, R., Holzer, H., \& Lerman, R. (2009). Promoting economic mobility by increasing postsecondary education. Philadelphia: Pew Charitable Trusts.

Hernandez, E., Mobley, M., Coryell, G., Yu, E., \& Martinez, G. (2013). Examining the cultural validity of a college student engagement survey for Latinos. Journal of Hispanic Higher Education, $12(2), 153-173$.

Herzog, S. (2005). Measuring determinants of student return vs. dropout/stopout vs. transfer: A first-tosecond year analysis of new freshman. Research in Higher Education, 46(8), 883-928.

Howard, J. (2003). Service-learning research: Foundational issues. In S. Billig \& A. Waterman (Eds.), Studying service-learning: Innovations in education research methodology (pp. 15-26). New York: Lawrence Erlbaum Publishing.

Hughes, K. (2012). The college completion agenda 2012 progress report. Retrieved from http://media.collegeboard.com/digitalServices/pdf/advocacy/policycenter/college-completionagenda-2012-progress-report.pdf

Hurtado, S. (2007). Linking diversity with the educational and civic missions of higher education. Review of Higher Education, 30(2), 185-196.

Hurtado, S., Han, J. C., Sáenz, V. B., Espinosa, L. L., Cabrera, N. L., \& Cerna, O. S. (2007). Predicting transition and adjustment to college: Biomedical and behavioral science aspirants' and minority students' first year of college. Research in Higher Education, 48(7), 841-887.

Kena, G., Musu-Gillette, L., Robinson, J., Wang, X., Rathbun, A., Zhang, J., Wilkinson-Flicker, S., Barmer, A., \& Dunlop Velez, E. (2015). The condition of education 2015 (NCES 2015-144). Washington, DC: U.S. Department of Education, National Center for Education Statistics. Retrieved from https://nces.ed.gov/pubs2015/2015144.pdf

Keup, J. R. (2005). The impact of curricular interventions on intended second-year enrollment. Journal of College Student Retention, 7(1), 61-89.

Kuh, G. (2008). High-impact practices: What they are, who has access to them, and why they matter. Washington, DC: Association of American Colleges and Universities.

Kuh, G. D., Kinzie, J., Buckley, J. A., Bridges, B. K., \& Hayek, J. C. (2011). Piecing together the student success puzzle: Research, propositions, and recommendations: ASHE higher education report (vol. 116). Hoboken, NJ: John Wiley \& Sons.

Levin, H. M., Belfield, C., Muennig, P., \& Rouse, C. (2007). The public returns to public educational investments in African American males. Economics of Education Review, 26(6), 699-708. 
Lockeman, K. S., \& Pelco, L. E. (2013). The relationship between service-learning and degree completion. Michigan Journal of Community Service Learning, 20(1), 18-30.

Mungo, M. H. (2017). Closing the gap: Can service-learning enhance retention, graduation, and GPAs of students of color? Michigan Journal of Community Service Learning, 23(2), 42-52.

Nelson, S. C., Bahrassa, N. F., Syed, M., \& Lee, R. M. (2015). Transitions in young adulthood: Exploring trajectories of parent-child conflict during college. Journal of Counseling Psychology, 62(3), 545551.

Pan, W., \& Bai, H. (Eds.) (2015). Propensity score analysis: Fundamentals and developments. New York: Guilford.

Pascarella, E. T., \& Terenzini, P. T. (2016). How college affects students: Findings and insights from 20 years of research. San Francisco: Jossey-Bass.

Pattanayak, C. W. (2015). Evaluating covariate balance. In W. Pan \& H. Bai (Eds.), Propensity score analysis (pp. 89-112). New York: Guilford.

Pearl, A. J., \& Christensen, R. K. (2017). First-year student motivations for service-learning: An application of the Volunteer Functions Inventory. Michigan Journal of Community Service Learning, 23(2), 66-82.

Pike, G. R., Hansen, M. J., \& Childress, J. E. (2014). The influences of students' pre-college characteristics, high school experiences, college expectations, and initial enrollment characteristics on degree attainment. Journal of College Student Retention, 16(1), 1-23.

Preis, J., \& Fenzel, L. M. (2003, April). Service-learning in the first-year seminar: Providing reciprocal benefits and enhancing connections. Paper presented at the Annual Meeting of the American Educational Research Association, Chicago, IL.

Próspero, M., \& Vohra-Gupta, S. (2007). First generation college students: Motivation, integration, and academic achievement. Community College Journal of Research and Practice, 31(12), 963-975.

Rama, D. V., Ravenscroft, S. P., Wolcott, S. K., \& Zlotkowski, E. (2000). Service-learning outcomes: Guidelines for educators and researchers. Issues in Accounting Education, 15(4), 657-692.

Reed, S. C., Rosenberg, H., Staham, A., \& Rosing, H. (2015). The effect of community service learning on undergraduate persistence in three institutional contexts. Michigan Journal of Community Service Learning, 21(2), 22-36.

Rosenbaum, P. R., \& Rubin, D. B. (1985). Constructing a control group using multivariate matched sampling methods that incorporate the propensity score. The American Statistician, 39(1), 33-38.

Ross, L., \& Boyle, M. E. (2007). Transitioning from high school service to college service-learning in a first-year seminar. Michigan Journal of Community Service Learning, 14(1), 53-64.

Song, W., Furco, A., Lopez, I, \& Maruyama, G. (2017). Examining the relationship between servicelearning participation and the educational success of underrepresented students. Michigan Journal of Community Service Learning, 24(1), 23-37.

Stavrianopoulos, K. (2008). Service learning within the freshman year experience. College Student Journal, 42(2), 703-712.

Stephens, N. M., Fryberg, S. A., Markus, H. R., Johnson, C. S., \& Covarrubias, R. (2012). Unseen disadvantage: How American universities' focus on independence undermines the academic performance of first-generation college students. Journal of Personality and Social Psychology, 102(6), 1178-1197.

Syed, M., \& Mitchell, L. L. (2013). Race, ethnicity, and emerging adulthood: Retrospect and prospects. Emerging Adulthood, 1(2), 83-95.

Tinto, V. (2003). Establishing conditions for student success. In L. Thomas, M. Cooper, \& J. Quinn (Eds.), Improving completion rates among disadvantaged students (pp. 1-10). Sterling, VA: Trentham Books Limited.

Tinto, V. (2012). Completing college: Rethinking institutional action. Chicago: University of Chicago Press. 
Vogelgesang, L. J., Ikeda, E. K., Gilmartin, S. K., \& Keup, J. R. (2002). Service-learning and the firstyear experience: Outcomes related to learning and persistence. In E. Zlotkowski (Ed.), Servicelearning and the first-year experience: Preparing students for personal success and civic responsibility (pp. 15-26). Columbia, SC: University of South Carolina, National Resource Center for the First-Year Experience and Students in Transition.

What Works Clearinghouse. (2017). Standards handbook (version 4.0). Retrieved from https://ies.ed.gov/ncee/wwc/Docs/referenceresources/wwc standards handbook_v4.pdf

Yue, H. \& Hart, S.M. (2017). Service-learning and graduation: Evidence from event history analysis. Michigan Journal of Community Service Learning, 23(2), 24-41.

Zlotkowski, E. (2002). Service-learning and the first-year experience: Preparing students for personal success and civic responsibility. Columbia, SC: University of South Carolina, National Resource Center for the First-Year Experience and Students in Transition. 